\title{
PENGARUH MODEL PEMBELAJARAN BERBASIS MASALAH \\ DAN KEMAMPUAN BERPIKIR KRITIS TERHADAP \\ KETERAMPILAN PEMECAHAN MASALAH FISIKA SISWA SMK
}

\author{
Muhammad Zunanda dan Karya Sinulingga \\ Prodi Pendidikan Fisikan Pascasarjana Universitas Negeri Medan \\ mzunanda@gmail.com
}

\begin{abstract}
Abstrak. Penelitian ini bertujuan untuk menganalisis perbedaan keterampilan pemecahan masalah fisika siswa pada model pembelajaran problem based learning dan pembelajaran konvensional, perbedaan keterampilan pemecahan masalah fisika siswa antara siswa yang memiliki kemampuan berpikir di atas rata-rata dan siswa yang memiliki kemampuan berpikir kritis di bawah rata-rata, serta interaksi antara model pembelajaran dengan kemampuan berpikir kritis dalam mempengaruhi keterampilan pemecahan masalah fisika siswa. Penelitian ini merupakan penelitian quasi eksperimen. Pemilihan sampel dilakukan dengan teknik cluster random sampling sebanyak dua kelas, dimana kelas pertama diajarkan dengan model pembelajaran berbasis masalah dan kelas kedua dengan pembelajaran konvensional. Instrumen yang digunakan terdiri dari tes keterampilan pemecahan masalah dan tes kemampuan berpikir kritis. Data dalam penelitian ini dianalisis dengan menggunakan anava dua jalur. Hasil penelitian menunjukkan bahwa keterampilan pemecahan masalah fisika siswa yang menggunakan model pembelajaran berbasis masalah lebih baik dibandingkan dengan pembelajaran konvensional, keterampilan pemecahan masalah fisika siswa dengan kemampuan berpikir kritis di atas rata-rata menunjukkan perbedaan dan hasil yang lebih baik dari pada siswa dengan kemampuan berpikir kritis di bawah rata-rata, serta terdapat interaksi antara model pembelajaran berbasis masalah dan kemampuan berpikir kritis dalam mempengaruhi keterampilan pemecahan masalah fisika siswa.
\end{abstract}

Kata kunci: model pembelajaran berbasis masalah, kemampuan berpikir kritis, keterampilan pemecahan masalah

\section{THE EFFECT OF MODEL PROBLEM BASED LEARNING AND ABILITY TO CRITICAL THINKING TO SKILLS PHYSICS RESOLUTION SMK STUDENTS}

\author{
Muhammad Zunanda dan Karya Sinulingga \\ Physics Education Program, Graduate State University of Medan \\ mzunanda@gmail.com
}

\begin{abstract}
The aims of this research were to analyzed the differences of student's problem solving skills by using problem based learning model and conventional learning, the differences of student's problem solving skills who had under average and above average category in critical thingking,
\end{abstract}


and the interaction between learning model and the level of critical thingking in influencing student's problem solving skills. This research was a quasi-experimental research. The sample in this research was conducted by cluster random sampling of two classes, which the first class, as experiment class, was taught with Problem Based Learning Model, as a control class, with Conventional Learning. The research instrument consisted of problem solving skills test and critical thingking test. Data in this research was analyzed by using two way Anova. The results of the research showed that the student of physic's problem solving skills using problem based learning model was differ and show better results than the conventional learning, the physics problem solving skills of the students who had above average category in critical thingking was differ and show better results than under average category, and there was interaction between problem based learning model and the level of critical thingking in influencing student of physic's problem solving skills.

\section{Keywords: problem based learning model, critical thingking, problem solving skill}

\section{PENDAHULUAN}

Pendidikan adalah suatu proses belajar mengajar yang berlangsung secara efektif dan efisien, secara terbuka dan bertanggung jawab yang disampaikan melalui kegiatan formal dan nonformal antara guru dan siswa. Diketahui banyak prestasi siswa-siswi Indonesia yang telah ditorehkan dalam dunia pendidikan diantaranya kemenangan dalam olimpiade sains internasional, karya ilmiah, teknologi robotik dan bahkan menjadi juara umum dengan mengalahkan negara-negara pesaing lain. Melalui gambaran tersebut Indonesia telah memiliki pendidikan yang mampu menjadi pendidikan yang bersaing dan berkualitas tinggi di mata dunia dimana makna berkualitas pada dasarnya adalah lebih mengarah pada sesuatu yang baik, Glaser (dalam Uno, 2009). Namun, di dalam data UNESCO melalui Education of All (EFA) Global Monitroring Report 2011, pendidikan Indonesia masih berada pada peringkat 69 dari 127 negara yang masih di bawah dibandingkan negara kawasan asia tenggara, kompas (Rahardjo, 2011).

Fisika merupakan salah satu pembelajaran sains memiliki peranan dalam mengembangkan ilmu pengetahuan di dunia pendidikan, mengajak siswa untuk berpikir aktif dan kreatif dan berperan penting dalam membentuk karakter seseorang yaitu karakter berpikir kognitif, afektif dan psikomotorik yang bersaskan sikap pengetahuan yang tinggi dalam memecahkan suatu fenomena alam. Selain sebagai bagian dari pengembangan karakter, fisika merupakan pengetahuan yang berisi konsep yang menguji analisis berpikir seseorang dalam menafsirkan dan menentukan hal-hal yang diperoleh pada saat melakukan kegiatan eksperimen atau investigasi. Sehingga melalui serangkaian kegiatan eksperimen, proses berpikir siswa dapat dimanfaatkan dengan baik dalam mengembangkan dan menciptakan kemampuan berpikir kognitif intelektual siswa. Adapun kemampuan berpikir yang diduga mampu dalam memecahkan suatu permasalahan fisika adalah kemampuan berpikir kritis siswa. Berpikir kritis adalah kegiatan berpikir yang dilakukan dengan mengoperasikan potensi intelektual untuk menganalisis, membuat pertimbangan dan mengambil keputusan secara tepat dan melaksanakannya secara benar, Ngalimun (2014) sehingga melalui penelitian ini kemampuan berpikir kritis yang diduga mempengaruhi pengetahuan siswa diukur pada kemampuan berpikir kritis memberikan 
penjelasan sederhana (elementary clarification), membangun keterampilan dasar (basic support), menyimpulkan (interference), memberikan penjelasan lebih lanjut (advanced clarification), serta mengatur strategi dan taktik (strategy and tactics), Ennis (dalam Costa, 1985).

Belajar adalah tidak ubahnya sebuah perilaku yang mengubah siswa dari kurang terampil, berkarakter dan berpengetahuan menjadi terampil, berwawasan ke depan dalam memecahkan suatu permasalahan fisika. Keterampilan problem solving adalah karakter umum dari struktur kognitif manusia yang merupakan proses mental yang meliputi empat aktivitas besar berupa identifikasi, memahami, menyelesaikan dan mengevaluasi masalah. Posamentier dan Jay (1999) mengungkapkan problem solving adalah suatu proses mengaplikasikan pengetahuan yang telah diperoleh sebelumnya ke dalam suatu situasi yang baru dan tidak dikenal. Atau suatu proses mental dan intelektual dalam menemukan masalah dan memecahkan berdasarkan data dan informasi yang akurat, sehingga dapat diambil kesimpulan yang tepat dan cermat, Hamalik (Yasin, 2009).

Berpikir memecahkan masalah dan menghasilkan sesuatu yang baru adalah kegiatan yang kompleks yang berhubungan erat satu dengan yang lain. Model pembelajaran berbasis masalah (problem based learning) sangat realistis untuk pembelajaran sains yang melibatkan kecerdasan emosional dan pemikiran konsep siswa. Problem Based Learning (PBL) adalah suatu pendekatan pembelajaran dengan membuat konfrontasi pada pembelajar dengan masalah-masalah praktis, berbentuk illstructured, atau open ended melalui stimulus dalam belajar, Boud dan Fogarty (Ngalimun, 2014). Lebih lanjut Arends (2008) menyatakan bahwa ada tiga hasil belajar (outcomes) yang diperoleh pebelajar yang diajarkan dengan PBL yaitu inkuiri dan keterampilan melakukan pemecahan masalah fisika, belajar model peraturan orang dewasa (adult role behaviours) dan keterampilan belajar mandiri (skills for independent learning). Dimana inkuiri dan keterampilan proses akan menggunakan kemam- puan berpikir kritis tingkat tinggi (higher order thinking skill) dalam melakukan operasi mental seperti induksi, deduksi, klasifikasi dan reasoning.

Pembelajaran berbasis masalah merupakan salah satu model pembelajaran yang menunjang dalam proses pembelajaran kurikulum 2013. Menurut Arends (2008), terdapat lima fase sintaks secara umum dalam model pembelajaran berbasis masalah, yaitu orientasi permasalahan, pengorganisasian untuk meneliti, investigasi, mengembangkan dan presentasi serta menganalisis dan presentasi. Pembelajaran ini mengharuskan guru untuk mengembangkan keterampilan kolaborasi diantara siswa dan membantu siswa dalam menginverstigasi masalah secara bersama-sama dan menjadi pelajar yang mandiri.

\section{METODE PENELITIAN}

Populasi dalam penelitian ini adalah seluruh siswa kelas XI SMK Dharma Analitika Medan yang terdiri dari 4 kelas paralel. Sampel dalam penelitian ini diambil 2 kelas dengan cara cluster random sampling dimana kelas yang dijadikan penelitian adalah kelas XI SMK Dharma Analitika Medan yang terdiri dari kelas XI-A sebagai eksperimen dan kelas XI-B sebagai kontrol.

Variabel dalam penelitian ini terdiri dari tiga jenis, yaitu: 1) Variabel bebas terdiri dari model pembelajaran problem based learning dan konvensional. 2) Variabel moderator adalah kemampuan berpikir kritis, 3) Variabel Terikat adalah keterampilan pemecahan masalah fisika siswa pada materi pokok listrik dinamis.

Penelitian ini menggunakan metode quasi eksperimen. Penelitian quasi eksperimen adalah penelitian yang menggunakan kelompok subjek secara utuh dalam eksperimen yang secara alami sudah terbentuk dalam kelas dan tidak mengontrol semua variabel yang ada. Penelitian ini melibatkan dua kelas yaitu kelas eksperimen dan kelas kontrol yang diberi perlakuan berbeda. Pada kelas eksperimen diberi perlakuan model pembelajaran problem based 
learning, sedangkan pada kelas kontrol diberi perlakuan dengan menggunakan pembelajaran konvensional. Adapun rancangan penelitian seperti Tabel 1 sebagai berikut:

Tabel 1. Rancangan Penelitian

\begin{tabular}{lccc}
\hline \multicolumn{1}{c}{ Kelas } & Pretes & Perlakuan & Postes \\
\hline Eksperimen & $\mathrm{T}_{1}$ & $\mathrm{X}_{1}$ & $\mathrm{~T}_{2}$ \\
\hline Kontrol & $\mathrm{T}_{1}$ & $\mathrm{X}_{2}$ & $\mathrm{~T}_{2}$ \\
\hline
\end{tabular}

Keterangan:

$\mathrm{T}_{1}=$ Test kemampuan awal (pre-test)

$\mathrm{T}_{2}=$ Test kemampuan akhir (post-test)

$\mathrm{X}_{1}=$ Perlakuan pada kelas eksperimen yaitu penerapan pengajaran Problem based learning

$\mathrm{X}_{2}=$ Perlakuan pada kelas kontrol yaitu penerapan pembelajaran konvensional

\section{HASIL PENELITIAN DAN PEMBAHASAN}

\section{Analisis Data Postes Keterampilan}

\section{Pemecahan Masalah}

Terlihat peningkatan rata-rata keterampilan pemecahan masalah fisika sebelum dan sesudah diberi perlakuan sebesar 50,19 sedangkan kelas eksperimen mengalami peningkatan rata-rata sebesar 55,89. Maka dapat disimpulkan bahwa peningkatan keterampilan pemecahan masalah siswa kelas yang dibelajarkan dengan model pembelajaran berbasis masalah lebih baik dari pada kelas kontrol yang dibelajarkan dengan pembelajaran konvensional.

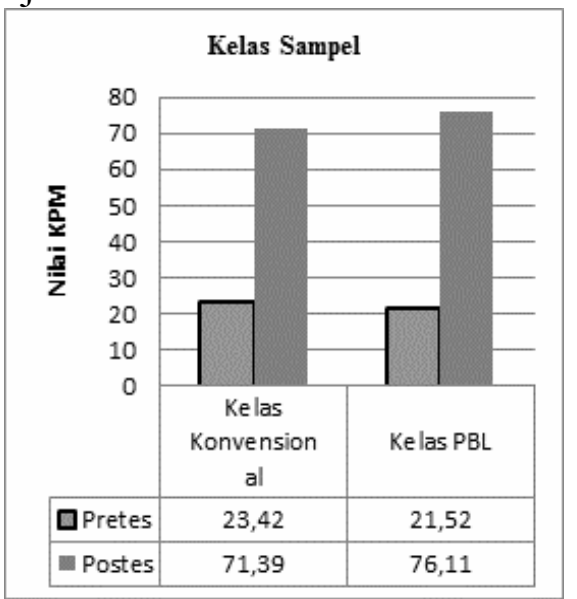

Gambar 1. Hubungan nilai keterampilan pemecahan masalah (KPM) terhadap model pembelajaran
2. Analisis Data Keterampilan Pemecahan Masalah Berdasarkan Tingkat Kemampuan Berpikir Kritis

Berdasarkan data pembagian kelompok berpikir kritis tinggi dan rendah gambar 2 menunjukkan rata-rata keterampilan pemecahan masalah (KPM) fisika siswa yang memiliki tingkat kemampuan berpikir kritis di bawah rata-rata pada kelas kontrol sebesar 61.85 dan kelas ekperimen adalah 71,50. Sedangkan ratarata keterampilan pemecahan masalah siswa yang memiliki tingkat kemampuan berpikir kritis (KBK) di atas rata-rata pada kelas kontrol sebesar 80.93 dan di kelas ekperimen sebesar 81.88. Hasil ini menunjukkan bahwa nilai ratarata keterampilan pemecahan masalah siswa di kelas ekperimen lebih tinggi dari pada kelas konvensional baik di tingkat berpikir kritis tinggi maupun rendah.

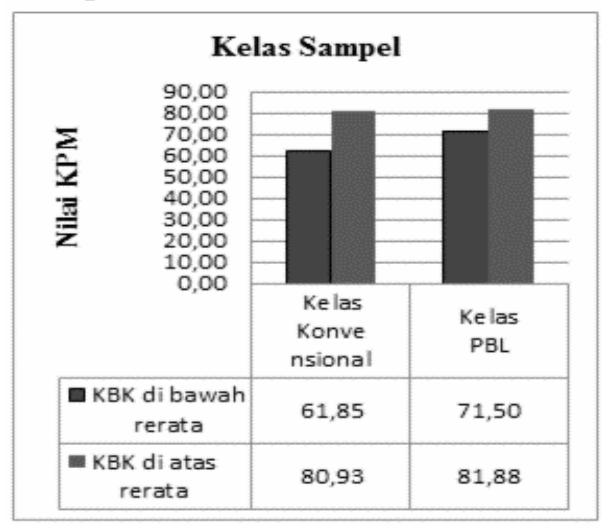

Gambar 2. Hubungan nilai keterampilan pemecahan masalah (KPM) berdasarkan tingkat kemampuan berpikir kritis (KBK)

Selanjutnya pada pengujian ANAVA dua jalur. Diperoleh hasil pengujian seperti terlihat pada Tabel 2.

Tabel 2. Hasil Uji Anava Dua Jalur

\begin{tabular}{|c|c|c|c|c|c|}
\hline Source & $\begin{array}{l}\text { Type III } \\
\text { Sum of } \\
\text { Squares }\end{array}$ & df & $\begin{array}{l}\text { Mean } \\
\text { Square }\end{array}$ & $\mathrm{F}$ & Sig. \\
\hline Corrected Model & $4632.577^{\mathrm{a}}$ & 3 & 1544.192 & 19.428 & .000 \\
\hline Intercept & 392227.682 & 1 & 392227.682 & 4934.66 & .000 \\
\hline $\begin{array}{l}\text { Kemampuan } \\
\text { Berpikir Kritis }\end{array}$ & 3878.376 & 1 & 3878.376 & 48.794 & .000 \\
\hline Model & 502.216 & 1 & 502.216 & 6.318 & .014 \\
\hline $\begin{array}{l}\text { Kemampuan } \\
\text { Berpikir Kritis * } \\
\text { Model }\end{array}$ & 338.417 & 1 & 338.417 & 4.258 & .043 \\
\hline Error & 5404.923 & 68 & 79.484 & & \\
\hline Total & 401650.000 & 72 & & & \\
\hline Corrected Total & 10037.500 & 71 & & & \\
\hline
\end{tabular}

a. R Squared $=.462$ (Adjusted R Squared $=.43$ 
Hasil interaksi antara model pembelajaran dan tingkat kemampuan berpikir kritis dalam mempengaruhi keterampilan pemecahan masalah juga dapat disajikan dalam bentuk grafik. Gambar 3. menunjukkan grafik interaksi antara model pembelajaran dan kemampuan berpikir kritis.

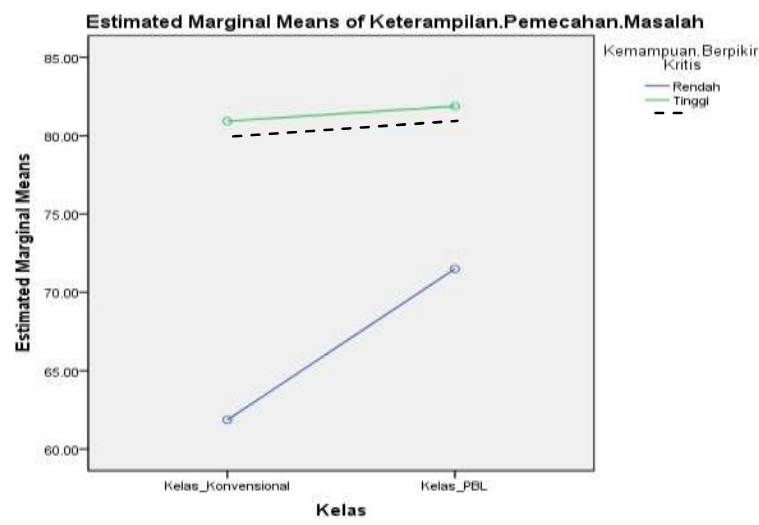

Gambar 3. Interaksi Antara Model PBL dan pembelajaran konvensional dengan kemampuan berpikir kritis

Gambar hasil interaksi antara model pembelajaran dengan tingkat kemampuan berpikir kritis di atas tidak dapat dilihat secara langsung adanya perpotongan garis, namun apabila kedua garis diperpanjang maka akan terlihat perpotongan garis yang akan terjadi di suatu titik. Hal ini menunjukkan interaksi antara model pembelajaran dan kemampuan berpikir kritis dalam penelitian ini kecil dengan signifikansi 0,043 .

\section{Pembahasan}

Membahas tujuan penelitian yang menganalisis perbedaan keterampilan pemecahan masalah fisika siswa yang menggunakan model pembelajaran problem based learning dengan model konvensional diperoleh hasil yang cukup signifikan sebesar 0,014 antara keterampilan pemecahan masalah fisika siswa yang menggunakan model pembelajaran berbasis masalah dengan konvensional, dimana rata-rata keterampilan pemecahan masalah siswa kelas ekperimen sebesar 76,11 lebih tinggi daripada kelas konvensional yang hanya sebesar 71,39 yang berarti terdapat hasil yang baik dengan menggunakan model pembelajaran berbasis masalah dibandingkan dengan konvensional.

Hasil ini sejalan dengan penelitian Ferreira dan Trudel (2012), yang mengemukakan bahwa pembelajaran berbasis masalah dapat meningkatkan secara signifikan keterampilan pemecahan masalah fisika siswa. Hal yang sama juga diperoleh Aydogdu (2012) bahwa pada kelas eksperimen siswa yang diajarkan dengan model pembelajaran berbasis masalah memiliki hasil yang lebih tinggi jika dibandingkan dengan kelas kontrol yang diajarkan dengan metode tradisional.

Sesuai dengan pendapat Melek dan Belma (2010) yang mengungkapkan pembelajaran berbasis masalah menyediakan lingkungan fungsional yang mana pelajar bersama teman dan dukungan guru menerima rekomendasi dan timbal balik ketika mengahadapi permasalahan yang mana kegiatan pembelajaran berganti dari satu arah ke berbagai arah disertai masalah dan ketersediaan solusi. Selain itu Alper (2008) juga berpendapat siswa terlihat lebih berani dalam mengembangkan hipotesis untuk memecahkan masalah dan mempunyai kemampuan lebih untuk menguji dan mengeliminasi hipotesis, sedangkan tanpa diskusi siswa lebih ragu dalam mengeliminasi hipotesis.

Redhana (2013) juga berpendapat pembelajaran berbasis masalah menyediakan masalahmasalah kurang terstruktur. Masalah kurang terstruktur adalah masalah yang tidak mengandung informasi yang lengkap dan semua informasi yang tersedia dalam masalah tidak cukup untuk memecahkan masalah tersebut. Oleh karena itu, untuk dapat memecahakan masalah tersebut, mahasiswa harus mengumpulkan informasi tambahan dari berbagai sumber. Bahkan, informasi tambahan ini harus dikumpulkan dalam jumlah yang banyak agar mahasiswa dapat memecahkan masalah kurang terstruktur tersebut dengan baik.

Melalui penelitian ini yang bertujuan menganalisis perbedaan keterampilan pemecahan masalah fisika siswa pada kelompok kemampuan berpikir kritis di atas rata-rata dan kelompok kemampuan berpikir kritis di bawah 
rata-rata diperoleh data perbedaan yang cukup signifikan sebesar 0,00 . Selain itu dari analisis rata-rata hasil keterampilan pemecahan masalah pada kemampuan berpikir kritis tinggi memiliki nilai yang lebih tinggi jika dibandingkan dengan siswa yang memiliki kemampuan berpikir kritis rendah dimana kelas eksperimen sebesar 81,88 dan kelas kontrol sebesar 80,93, sedangkan kemampuan berpikir kritis rendah kelas eksperimen 71,50 dan kelas kontrol sebesar 81,88 .

Temuan penelitian ini sejalan dengan hasil penelitian yang telah dilakukan oleh Burris dan Bryan (2007) yang menunjukkan bahwa ada pengaruh perlakuan dengan kemampuan berpikir kritis dan konten pengetahuan siswa. Selain itu Astika (2013) menyatakan terdapat perbedaan yang signifikan kemampuan berpikir kritis antara siswa yang belajar menggunakan model pembelajaran berbasis masalah dengan siswa yang belajar menggunakan model pembelajaran ekspositori. Kemampuan berpikir kritis berpengaruh terhadap prestasi kognitif, afektif, dan psikomotorik siswa. Selanjutnya El-Shaer (2014) menyatakan terdapat peningkatan yang signifikan secara statistik dalam postes berpikir kritis siswa dibanding sebelum perlakuan dimana item kepercayaan diri berpikir kritis mempunyai perubahan persentase yang tinggi serta diikuti dengan keingintahuan dan kedewasaan siswa.

Tampak pada kegiatan pembelajaran, siswa dengan kemampuan berpikir kritis rendah menunjukkan aktivitas yang rendah, baik dalam pengorganisasian, pelaksanaan kegiatan investigasi maupun kegiatan penyajian hasil dan laporan yang telah dilakukan. Kecenderungankecenderungan tersebut mengakibatkan siswa dengan kemampuan berpikir kritis rendah tidak memiliki kemampuan menganalisa dan mensintesis permasalah yang dihadapi. Hal ini sejalan dengan pendapat El-Shaer dan Hala (2014) bahwa pembelajaran berbasis masalah berkontribusi menolong siswa untuk berpartisipasi secara aktif dalam kelas perawat, menyediakan kemampuan berpikir kritis yang memungkinkan siswa untuk melengkapi kebutuhan harapan dan menggunakan pengetahuan dalam membuat materi pelajaran lebih menarik dan lebih relevan. Sedangkan Thoman (2009) mengungkapkan perkembangan berpikir adalah elemen berpikir kritis dalam hubungan pendidikan berkelanjutan. Masek dan Sulaiman (2011) PBL mempunyai potensi yang besar dalam membantu mengembangkan keterampilan berpikir tingkat tinggi khususnya kemampuan berpikir kritis.

Hasil pengujian dengan menggunakan uji scheffe dalam melihat interaksi model pembelajaran dengan kemampuan berpikir kritis dalam meningkatkan keterampilan pemecahan masalah fisika siswa diperoleh hasil yang signifikan sebesar 0,043. Terdapat interaksi dalam penelitian ini bisa disebabkan karena kemampuan berpikir kritis siswa berperan penting dalam kematangan intelektual siswa. Selain itu pembelajaran berbasis masalah yang merupakan pembelajaran berpusat pada siswa membutuhkan pengetahuan pengembangan kemampuan berpikir dalam menyelesaikan suatu permasalahan terhadap situasi atau lingkungan belajar yang tidak siswa ketahui. Dan dengan pembelajaran ini siswa yang memiliki kemampuan berpikir kritis tinggi diajak untuk berpikir secara aktif dan partisipatif dalam mencari informasi, menganalisis dan memecahkan masalah dengan menggunakan sumber pembelajaran yang sesuai dengan permasalahan yang dihadapi. Sebaliknya model pembelajaran yang berinteraksi dengan kemampuan berpikir kritis rendah akan berinteraksi dengan hasil prestasi belajar yang rendah terhadap keterampilan pemecahan masalah. Hal ini dikarenakan siswa dengan kemampuan berpikir kritis rendah cenderung tidak mau tahu dan kurang paham dalam memecahkan suatu permasalahan yang siswa sulit dalam melakukan analisis, mengolah dan melaksanakan kegiatan pembelajaran yang menuntut aktivitas tinggi serta menguras pemikiran. Temel (2014) juga mengungkapkan hal yang sama, bahwa pembelajaran berbasis masalah mempunyai pengaruh positif dalam disposisi pemikiran kritis dan persepsi kemampuan pemecahan masalah. Terlebih guru dalam pembelajaran ini 
memperkenalkan sebuah pendekatan pembelajaran yang berbeda dari metode tradisional yaitu keterlibatan dalam lingkungan belajar yang tidak diketahui, yang diakui sebagai alasan yang tidak hanya cukup tingkatan kemahiran keterampilan berpikir, tetapi dalam proses ini, guru diberikan peluang dalam mengembangkan pembagian pemikiran kritis dan persepsi kemampuan pemecahan masalah.

Namun dengan menggunakan uji lanjut diperoleh hasil yang tidak signifikan perbedaan pembelajaran problem based learning dan konvensional pada kemampuan berpikir kritis tinggi yaitu sebesar 0,992. Dan dari grafik di atas, hasil yang lebih baik keterampilan pemecahan masalah siswa pada tingkat kemampuan berpikir kritis adalah pada kelas konvensional.

Dalam A Practitioner's Guide to Enquiry and problem based learning karangan Barret dan Cashman (2010) yang mengungkapkan masalah umum pembelajaran berbasis masalah adalah frustasi terhadap waktu yang habis hanya untuk menentukan objek dan mencari sumber sesuai dengan objek yang dituju. Sehingga Alper (2008) memperoleh sebanyak 45 persen siswa yang terlibat dalam pembelajaran PBL tidak menyukai belajar dengan membentuk kelompok, siswa lebih suka belajar berkelompok jika ditemukan solusi pelajaran yang berbeda yang berarti siswa ingin belajar sendiri jika ditemukan hasil jawaban yang berbeda dari teman yang lain. Jadi jika dihubungkan dengan disposisi berpikir kritis seseorang akan memperlihatkan keterampilanketerampilan yang ia miliki hanya pada situasi kondisi yang memiliki kredibilitas yang tepat ketika menghadapi suatu ujian atau keadaan yang memang harus mengeluarkan kemampuannya tetapi tidak menerapkannya dalam suatu kondisi kegiatan sehari-hari (Fisher, 2009).

\section{KESIMPULAN DAN SARAN}

Berdasarkan hasil penelitian yang dilakukan di sekolah SMK Dharma Analitika dengan menggunakan model pembelajaran problem based learning diperoleh kesimpulan:
Terdapat perbedaan keterampilan pemecahan masalah fisika siswa melalui model pembelajaran berbasis masalah (problem based learning) dengan model pembelajaran konvensional. Dimana nilai rata-rata pembelajaran berbasis masalah 76,69 yang berarti lebih baik jika dibandingkan kelas konvensional dengan nilai rata-rata 71,38. 2) Terdapat perbedaan keterampilan pemecahan masalah fisika siswa antara kelompok siswa yang memiliki kemampuan berpikir kritis di atas rata-rata dengan kelompok siswa yang memiliki kemampuan berpikir kritis di bawah rata-rata, dan keterampilan pemecahan masalah fisika siswa yang memiliki kemampuan berpikir kritis di atas rata-rata 81,40 lebih baik jika dibandingkan kelas konvensional 66,75. 3) Terdapat interaksi antara model pembelajaran berbasis masalah (problem based learning) dan kemampuan berpikir kritis dalam meningkatkan keterampilan pemecahan masalah fisika siswa dengan hasil interaksi pada kelas problem based learning sebesar 0,043 lebih baik dibanding konvensional. Berdasarkan hasil pembahasan dan simpulan, saran yang dapat dikemukakan adalah: 1) Pendidik hendaknya dapat memilah materi pembelajaran yang sesuai dengan model pembelajaran berbasis masalah (problem based learning) serta memperhatikan kelengkapan sumber belajar, bahan ajar yang diperlukan dalam mengoptimalkan pelaksanaan pembelajaran. 2) Dilihat dari karakter siswa, siswa belum terbiasa dengan menggunakan model pembelajaran berbasis masalah (problem based learning). 3) Melalui penerapan model pembelajaran berbasis masalah (problem based learning). 4) Peneliti lain yang ingin menggunakan model pembelajaran berbasis masalah (problem based learning) diharapkan dapat menggunakan variabel moderator lain selain kemampuan berpikir kritis dalam penelitian, karena selain model pembelajaran yang dapat mempengaruhi terhadap hasil pemecahan masalah, tetapi terdapat faktor lain yang bisa diklasifikasikan mempengaruhi pengetahuan siswa. 


\section{DAFTAR PUSTAKA}

Alper, Ayfer. 2008. Attitudes Toward Problem Based Learning in a New Turkish Medicine Curriculum. World Applied Sciences Journal, 4 (6): 830-836.

Arends, R.I. 2008. Learning to Teach. New York: Mc Graw Hill Companies.

Astika, I. Kd. Urip, K. Suma, I. W. Suastra. 2013. Pengaruh Model Pembelajaran Berbasis Masalah Terhadap Sikap Ilmiah dan Keterampilan Berpikir kritis. eJournal Program Pascasarjana Universitas Pendidikan Ganesha Program Studi IPA. Vol. 3: 26-34.

Aydogdu, Cemil. 2012. The Effect of Problem Based Learning Strategy In Electrolysis and Battery Subject Teaching. H. U. Journal of Education. 42: 48-59

Barret, T., dan Cashman, D. 2010. A Practitioner's Guide to Enquiry and problem based learning: Case Studies from University College Dublin. Dublin: UCD Teaching and Learning.

Burris, Scott dan Bryan L. Garton. 2007. Effect of Instructional Strategy On Critical Thingking and Content Knowledge: Using Problem Based Learning In The Secondary Classroom. Journal of Agricultural Education, 48 (1): 106-116.

Costa, Arthur L. 1985. Developing Minds, A Resource Book for Teaching Thinking. Virginia: ASCD

El-Shaer, Ahlam dan Hala Gaber. 2014. Impact of Problem Based Learning on students' Critical Thinking Dispositions, Knowledge Acquisition and Retention. Journal of Education and Practice. 5 (14):74-85

Ferreira, Maria M. dan Trudel, A.R. 2012. The Impact of Problem-Based Learning (PBL) on Student Attitudes Toward Science, Problem-Solving Skills, and Sense of Community in the Classroom. Journal of Classroom Interaction. 47 (1):23-30.
Masek, Alias dan Sulaiman, Y. 2011. The Effect of Problem Based Learning on Critical Thinking Ability: A Theoretical and Empirical Review. International Review of Social Sciences and Humanities. 2 (1):215-221.

Melek, D., dan Belma A.T. 2010. The Effects Of Problem Based Learning On Achievement, Attitude, Metacognitive Awareness And Motivation. Hacettepe Üniversitesi Ĕ̈itim Fakültesi Dergisi (H. U. Journal of Education). 38:55-66.

Ngalimun. 2014. Strategi dan Model Pembelajaran. Yogyakarta: Aswaja Pressindo.

Posamentier, Alfred S. and Jay Steppelman. 1999. Teaching Secondary Mathematics: Techniques and Enrichment Units. New Jersey: Prentice-Hall, Inc.

Rahardjo, M. 2011. http://www.mudjiarahardjo.com/artikel/315-peringkatpendidikan-indonesia-menurun.html. diakses 6 Februari 2014.

Redhana, I.,W. 2013. Model Pembelajaran Berbasis Masalah untuk Peningkatan Keterampilan Pemecahan Masalah dan Berpikir Kritis. Jurnal Pendidikan dan Pengajaran. 46 (1): 76-86.

Temel, Senar. 2014. The effects of problembased learning on pre-service teachers' critical thinking dispositions and perceptions of problem-solving ability. South African Journal of Education. 34 (1): $1-20$.

Thoman, Ias. 2009. Critical Thinking, Transformative Learning, Sustainable Education, and Problem-Based Learning in Universities. Journal of Transformative Education. 7(3): 245-264.

Uno, H.B. 2009. Model Pembelajaran. Jakarta: Bumi Aksara

Yasin, S. 2009. http://www.sarjanaku.com /2011/03/pengertian-problem-solving. html. diakses 21 Maret 2015. 